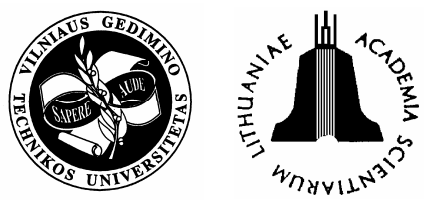

\title{
NEW APPROACHES TO ANALYSIS AND DESIGN OF A STATIONARY COVERING ABOVE THE STADIUM TRIBUNES
}

\author{
Yevheny Horokhov, Vladimir Mushchanov, Vadim Kasimov \\ Donbass National Academy of Civil Engineering and Architecture, \\ Dergavin st. 2, Makeevka, Donetsk reg., Ukraine.E-mail: mvf@dgasa.dn.ua
}

Received 4 Aug 2005; accepted 26 Oct 2005

\begin{abstract}
The stationary covering above tribunes of a stadium is reviewed as a truncated rod shell of positive curvature in the elliptical plan. The system of dimensionless spatially-rigid parameters is obtained for this structure, and it stipulates features of stressed and deformed state of structure under the influence of assumed loads. The results of numerical and experimental studies, original positions of the suggested engineering procedure of design and calculation, results of experimental designing are adduced.
\end{abstract}

Keywords: dimensionless spatial rigid parameters, spatial-rod system, continual envelope.

\section{Introduction}

At present the stationary covering of the stadium tribunes is considered to be one of the most dynamically developing types of spatial large-span structures which are of great interest from the architectural and structural points of view. They are erected in accordance with the requirements of international football organisations. Both for renovated [1] and for new stadiums, the special notice is given to problems of elaboration of analysis and designing methods [2], and to wind load capacities [3-5]. The considerable contribution is made by the explorers to the elaboration of specialised software products for computer designing of studied constructions $[6,7]$. The international experience of designing and erecting such structures has not found its application in Ukraine yet (in Russia, Luzhniky [8] stadium has such coverings). Besides the best part of the Ukrainian stadiums are of a smaller size (initially for 40-45 thousand people, after providing with individual sits for 28-31 thousand people). It reduces the

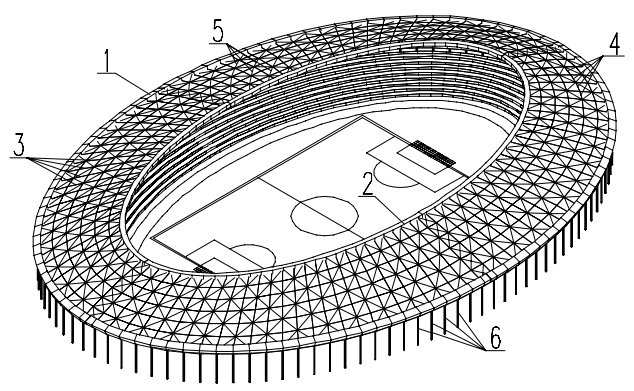

Fig 1. Spatial rod covering in the shape of truncated dome: 1 - external and 2 - internal index contours, 3 - radial, 4 - ring and 5 - diagonal elements, 6 - internal index contour columns efficiency of structures spatial performance and requires additional research aimed to setting their rational geometrical forms. The object of the present study is the spatially-rod large-cut shell (Fig 1) [9-12].

\section{The suggested analytical techniques of calculation}

a) The system of spatial-rigid dimensionless parameters

One of the main stages of this study is obtaining the system of spatial-rigid dimensionless parameters which allow to determine the basic bearing components rigidity characteristics at the initial stage of calculating. For this purpose the spatially rod sloping truncated shell is required to the equivalent continual shell with the thickness $t=\frac{A_{\kappa . p .}}{S_{\kappa . p .}}+\frac{A_{p . p .}}{S_{p . p .}}, A_{\kappa . p .}, A_{p . p .}$ is ring and radial ribs cross-sectional area; $S_{\kappa . p .}, S_{p . p .} S_{\kappa . p .}$ - ring and radial ribs step.

As initial data, the system of equilibrium equations along the line of shell adjunction to the contour was investigated (Fig 2a, b) [13, 14]. The equation $\sum M_{i 2}=0$ is not used because of the hinged fastening of the shell to contour.

$$
\left.\begin{array}{l}
\frac{\partial T_{1}}{\partial x}+\frac{\partial S}{\partial y}-\frac{\partial q_{x}^{\kappa H}}{\partial x}=0 \\
\frac{\partial T_{2}}{\partial y}+\frac{\partial S}{\partial x}-\frac{\partial N_{\kappa H}}{\partial y \cdot b_{\kappa H}}=0 \\
T_{1} \frac{\partial^{2} f}{\partial x^{2}}+T_{2} \frac{\partial^{2} f}{\partial y^{2}}-\frac{\partial q_{z}^{\kappa H}}{\partial x}-\frac{\partial q_{z}^{\kappa H}}{\partial y}=0 \\
\frac{\partial M_{1}}{\partial x}+\frac{\partial H}{\partial y}-\frac{\partial M_{x}^{\kappa H}}{\partial x \partial y}=0
\end{array}\right\}
$$


For obtaining the spatial-rigid dimensionless parameters the linear theory of shell calculation is used. The ringing efforts values in the equations (1.1) can be expressed in terms of relative deformations which, in their turn are expressed in terms of displacements.

The system of equations (1.1) will be given in displacements using the relations of the elasticity theory.

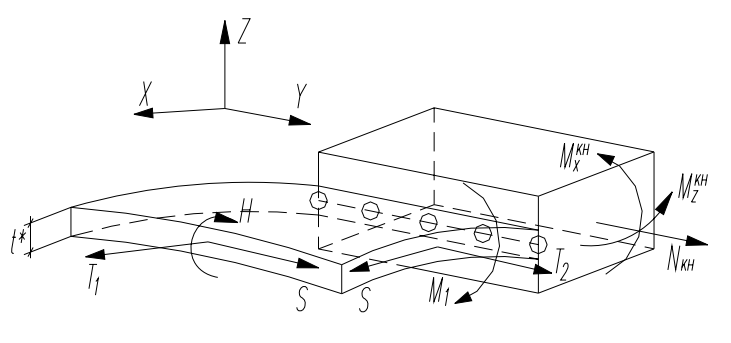

a)

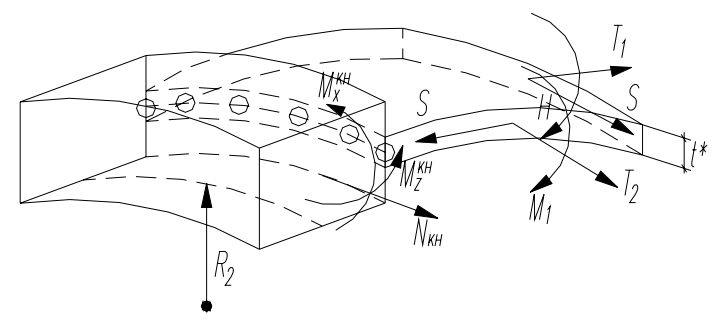

b)

Fig 2. Schemes of the adjunction of spatial rod system to: a - the external index contour, $\mathrm{b}$ - internal ring; $T_{1}$, $T_{2}$ - shell radial and ring running effort; $S$ - shell shifting running effort; $M, H$ - shell bending and twisting linear moments; $N_{k N}-$ index contour longitudinal effort, $M_{x}^{k N}, M_{z}^{k N}$ - bending moment within index contour about the axes $\mathrm{X}$ and $\mathrm{Y}$

$$
\left.\begin{array}{l}
B\left[\frac{\partial u}{\partial x}+\mu \frac{\partial v}{\partial y}-w(L+\mu N)\right]=E I_{z}^{\text {int }} \frac{\partial^{4} u}{\partial y^{4}} \\
B\left[\frac{\partial u}{\partial x}+\mu \frac{\partial v}{\partial y}-w(L+\mu N)\right]=E I_{z}^{e x t} \frac{\partial^{4} u}{\partial y^{4}} \\
{\left[\left(R_{2}^{2}-x^{2}\right) \frac{d^{4} w}{d x^{4}}+4 x \frac{d^{3} w}{d x^{3}}-\frac{d^{2} w}{d x^{2}}\right] \frac{E I_{y}^{\text {int }}}{R_{2}^{2}}=} \\
D\left[\frac{\partial^{3} w}{\partial y^{3}}+(2-\mu) \frac{\partial^{3} w}{\partial x^{2} \partial y}\right]
\end{array}\right\}
$$

Using dimensionless coordinates and relative displacements $\xi=\frac{x}{a}, \eta=\frac{y}{b}$ and $\bar{u}=\frac{u a}{t^{2}}, \bar{v}=\frac{v b}{t^{2}}, \bar{w}=\frac{w}{f}$ $[8,13,15,16]\left(\mathrm{a}, \mathrm{b}, \mathrm{a}_{1}, \mathrm{~b}_{1}\right.$ - internal and external index contours semi axes; $R_{2}$ - radius of curvature in radial direction in the plane XOZ; $b_{k N}, b_{1 k N}$ - horizontal size of the external and internal contours crosssection; $f$ - index contour rise; $I_{z}^{\text {ext }}, I_{z}^{\text {int. }}$ - bending rigidity of external and internal index contours in vertical plane; $I_{y}^{\text {int }}$ - bending rigidity of the internal index contour in horizontal plane). Necessary manipulation yields the system of dimensionless spatial-rigid parameters which can be used while investigating the general mechanism of the spatial structure stressed and deformed state change depending on the geometric and rigid characteristics change:

$$
\begin{aligned}
& {\left[\bar{D}_{1}=\frac{E I_{z}^{e x t} a b_{1}^{4}+E I_{z}^{\text {int }} a_{1} b^{4}}{E t b^{4} b_{1}^{4}}\right], \bar{D}_{2}=\frac{a^{2} b_{1}^{2}+a_{1}^{2} b^{2}}{b^{2} b_{1}^{2}},} \\
& \bar{D}_{3}=\frac{a_{1} f}{t^{2}}, \bar{D}_{1}{ }^{\prime}=\frac{E I_{z}^{e x t} a_{1} b_{1}^{2}+E I_{z}^{\text {int }} a b^{2}}{E t a b^{2} a_{1} b_{1}^{2}} \\
& {\left[\bar{D}_{4}=\frac{E I_{y}^{\text {int }} \cdot b}{E t^{3} R_{2}^{2}}\right], \bar{D}_{5}=\frac{E I_{y}^{\text {int }} \cdot b}{E t^{3} a^{2}}, \bar{D}_{6}=\frac{a^{2}}{b^{2}} .}
\end{aligned}
$$

\section{b) Numerical researches}

Using the obtained dimensionless spatial rigid parameters, the numerical experiment aimed to the abovementioned interrelations determination has been carried out. In the process of investigation there have been obtained the data and dependence of internal efforts in radial ribs oriented along the structure main semi axes and in the central part of the scheme quarter. The similar data have been obtained also for ring elements as well as for the internal index contour vertical displacements which should be given a special attention.

The study results are shown in Fig 3.

\section{An experimental research on the joint SSS by a large-scale model}

For testing the numeral experiment results and the adequacy of structure mathematical model (calculation scheme), an experimental study on a large-scale model of spatially rod covering has been carried out.

The geometrical dimensions of the covering model in the plan are $2 \mathrm{a} \times 2 \mathrm{~b}=2,5 \times 1,7 \mathrm{M}$ with a risem $f=170 \mathrm{~mm}$ [17].

The model general dimensions are designed in accordance with the sizes of tribunes of the stadium "Shakhtar" in Donetsk. The analogous tests of the covering model with dimensions $8,3 \times 10,3 \mathrm{~m}$ were carried out by MNEETEP and CNIISK, named after Kucherenko and joint-stock company "CNIIS" with "MNIIP". The covering model is designed in the scale 1:30 relatively to the original structure [9].

The object of the study is the spatially-rod shell with Gauss's positive curvature with the surface in the shape of elliptic paraboloid.

$$
f(x, y)=-\frac{x^{2}}{2 a^{2}}-\frac{y^{2}}{2 b^{2}}+c .
$$

In the modelling process the principle of geometrical similarity with the scale factor $m=1 / 100$ is used. The covering model was tested in the elastic phase under static loads. During the experiment the relative deforma- 
tions of the external and ring ribs were being measured; besides, the vertical displacement of the nodes of the internal contour and covering span section were being measured. Horizontal displacements were recorded for the internal index contour along the principal axis in the central part of structural scheme quarter; the scheme of measuring instruments location is given in Fig 4 b.

The schemes of model loading applied to the experiment are used in accordance with the experience of the previous research for the similar structures. The model general view of the testing process is in Fig 5 .

The load was applied by suspending small weights. The distributed load values are $\mathrm{q}=0,5732 \mathrm{kN} / \mathrm{m}^{2}$ and $\mathrm{s}=0,6865 \mathrm{kN} / \mathrm{m}^{2}$ for permanent and temporary load correspondingly. Temporary and permanent load was applied step-by-step and divided into 4 stages, $0,1433 \mathrm{kN} / \mathrm{m}^{2}$ and $0,1716 \mathrm{kN} / \mathrm{m}^{2}$. The dependences obtained during the experimental study have been processed by the least-squares technique using MathCAD,
Microsoft Excel. Figs 5-7 show some test results including the values of vertical displacement along the principal axes of the structure and by the perimeter of the internal index contour of the structure from load schemes shown in Fig 4 b. On the basis of the obtained results of theoretical and experimental research the authors have developed an algorithm of engineering design procedure for spatial-rod large cut shells which allow to estimate geometrical parameters, rigid parameters of the main bearing elements, parameters of the considered object intense-deformed state. Engineering design procedure is being developed on the basis of numerical experiment data in the course of it, dimensionless spatial rigid parameters were being varied $\bar{D}_{1}=\frac{E I_{z}^{e x t} a b_{1}^{4}+E I_{z}^{\text {int }} a_{1} b^{4}}{E t b^{4} b_{1}^{4}}$, $\bar{D}_{4}=\frac{E I_{y} b}{E t R^{2}}$ [13] (shell geometry, stiffness of an internal and external index contours).

a)

b)
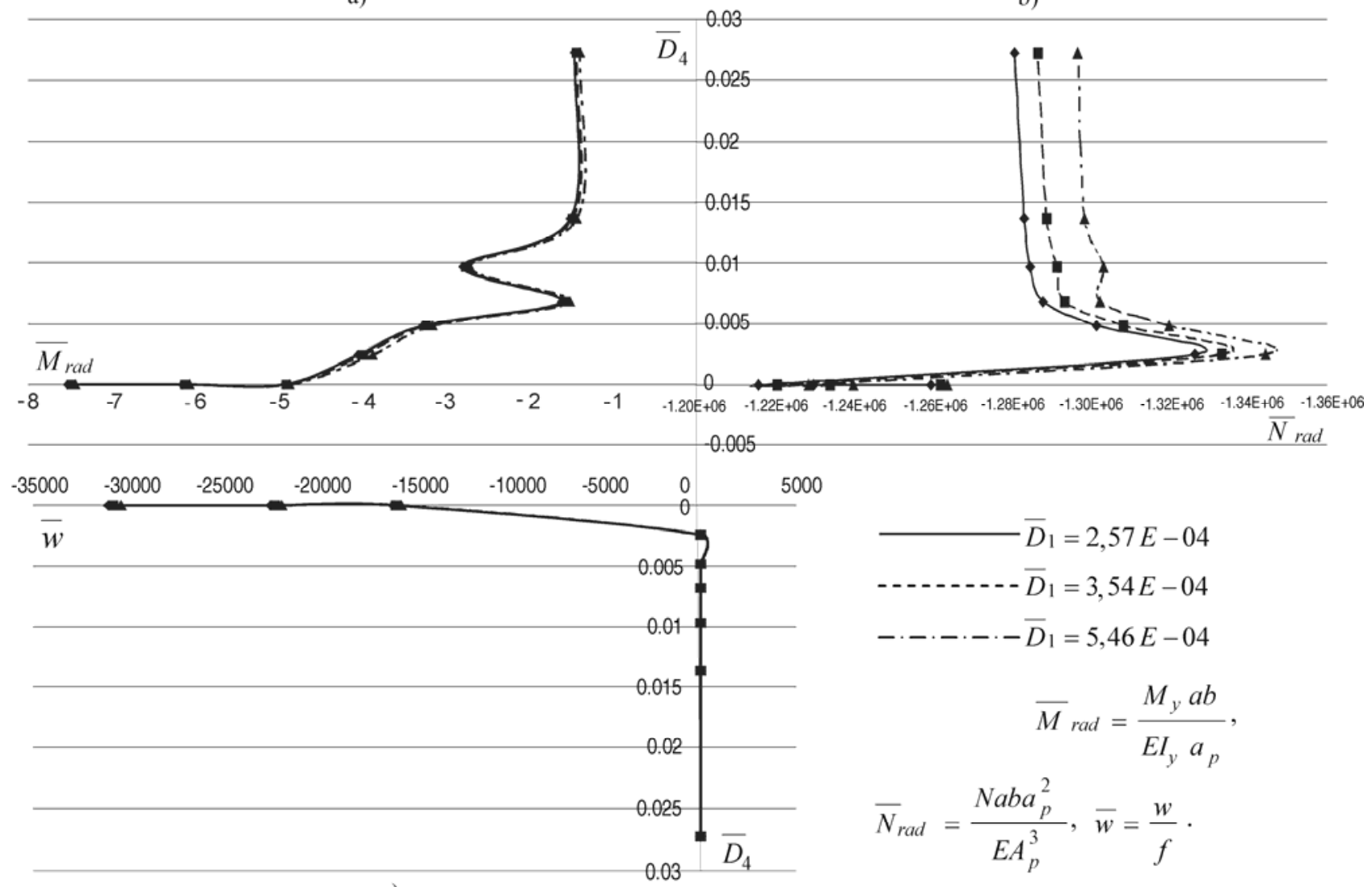

$$
\begin{array}{r}
\overline{D_{1}}=2,57 E-04 \\
----\bar{D}_{1}=3,54 E-04 \\
-\bar{D}_{1}=5,46 E-04 \\
\bar{M}_{\mathrm{rad}}=\frac{M_{y} a b}{E I_{y} a_{p}}, \\
\bar{N}_{\mathrm{rad}}=\frac{N a b a_{p}^{2}}{E A_{p}^{3}}, \bar{w}=\frac{w}{f} .
\end{array}
$$

Fig 3. The dependence of dimensionless parameters of stressed and deformed state for main bearing components on dimensionless spatial rigid parameters $\bar{D}_{1}, \bar{D}_{4}$ for elements, located along the long axis of structure: a) the bending moment effort dimensionless parameter $\bar{M}_{\text {rad }}$; b) the longitudinal effort dimensionless parameter $\bar{N}_{\text {rad }}$; c) vertical displacements dimensionless parameter $\bar{w}$ for internal index contour 
a)

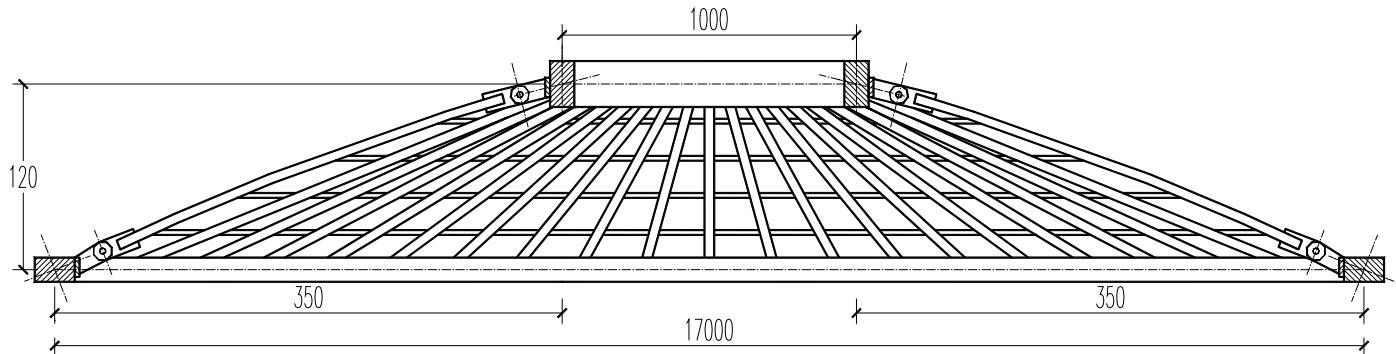

b)

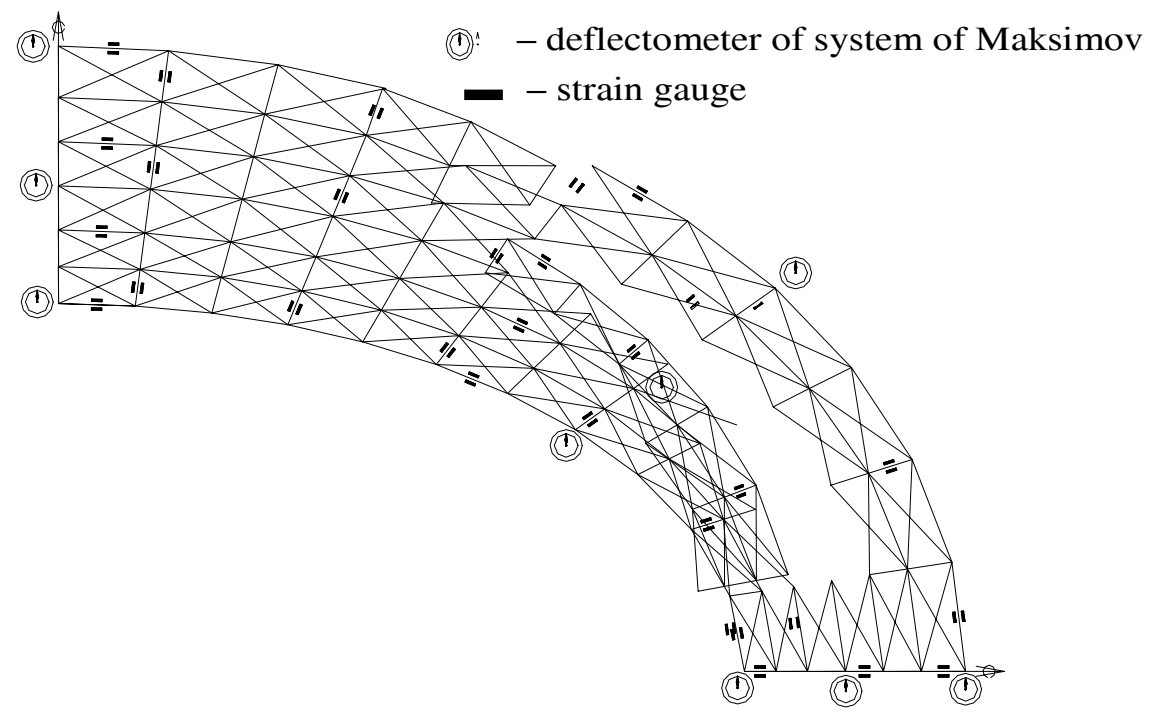

Fig 4. The model general view (a); measuring instruments location scheme (b)

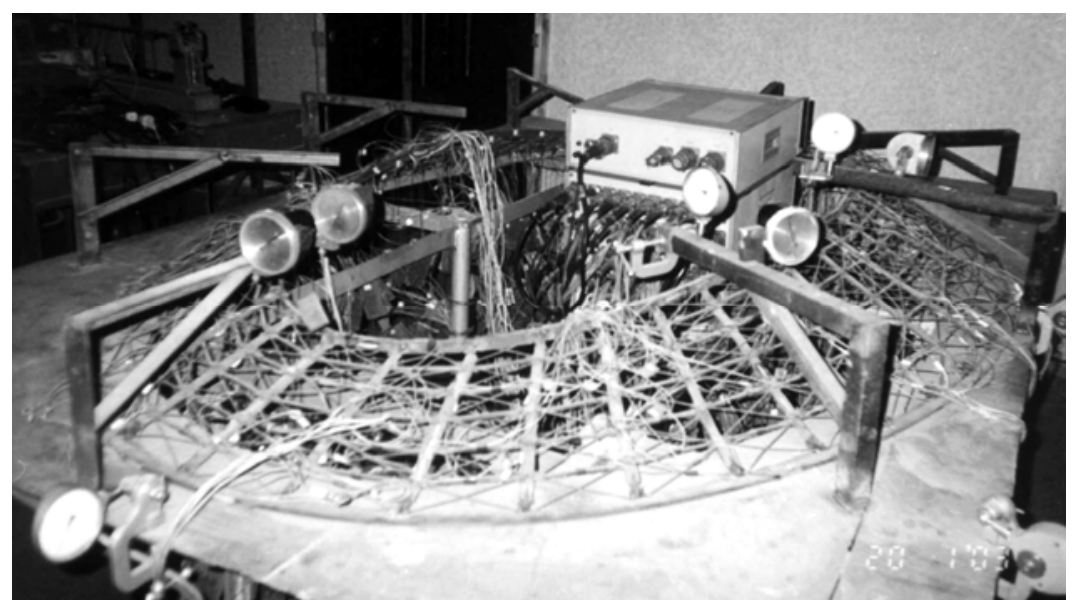

Fig 5. The general view of the spatial rod covering model in the testing process

\section{The suggested engineering procedure of design and calculation}

Engineering procedure is presented in the form of blocks in Fig 8 [18].

1. Determining mechanical and geometrical parameters of a structure.

2. Spacing of the basic bearing elements (radial and ring ribs).

3. Conventional radius of vertical plane which determines spatially rod shell geometry.
4. Accepting the value of dimensionless spatial rigid parameter $\bar{D}_{4}$.

5. Determining dimensionless spatial rigid parameter $\bar{D}_{1}$ by using dependence $\bar{W}=f\left(\bar{D}_{1}, \bar{D}_{2}\right)$ (Fig 9).

6. Finding values of dimensionless parameters of internal efforts in main bearing elements (radial and ring ribs external and internal index contours) (Fig 10).

7. Determining rigid characteristics of the main bearing elements (radial and ring ribs external and internal index contour) by using the recommended relation of the main bearing elements rigid characteristics. 
a)

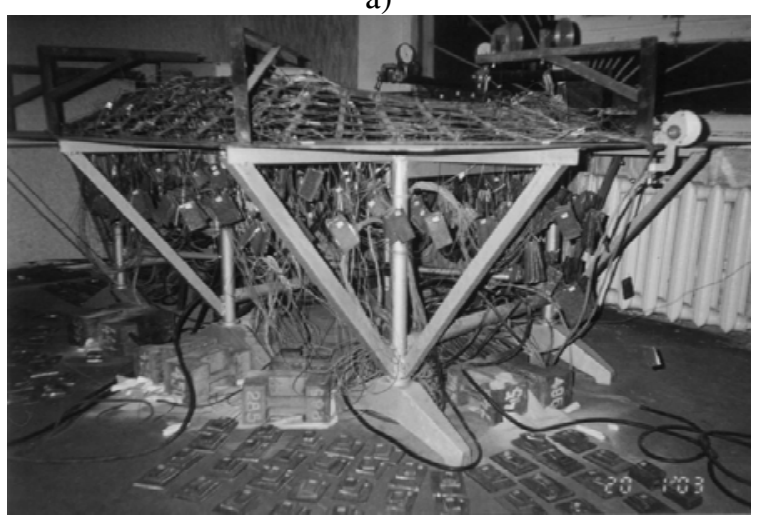

c)

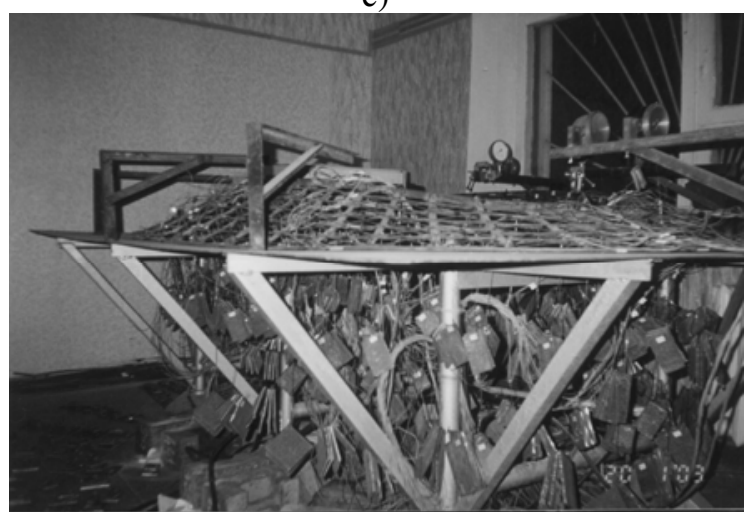

b)

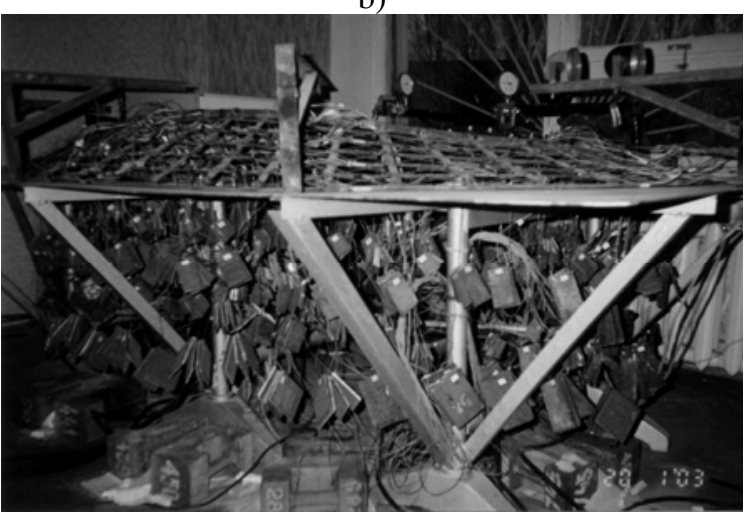

d)

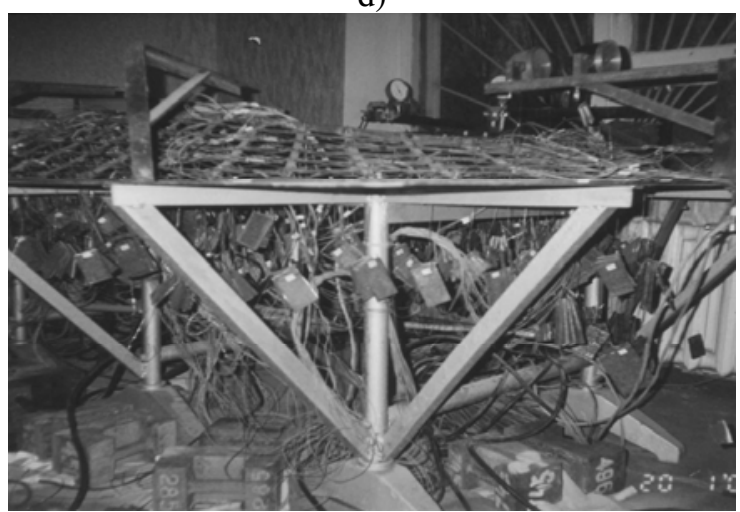

Fig 6. Model loading in the testing process: a - structure own weight; $b$ - structure own weight + temporary load all over the covering; $c-$ structure own weight + temporary load over the half of the covering semantically about the long axis; $d-$ structure own weight + temporary load over the half of the covering semantically about the short long axis

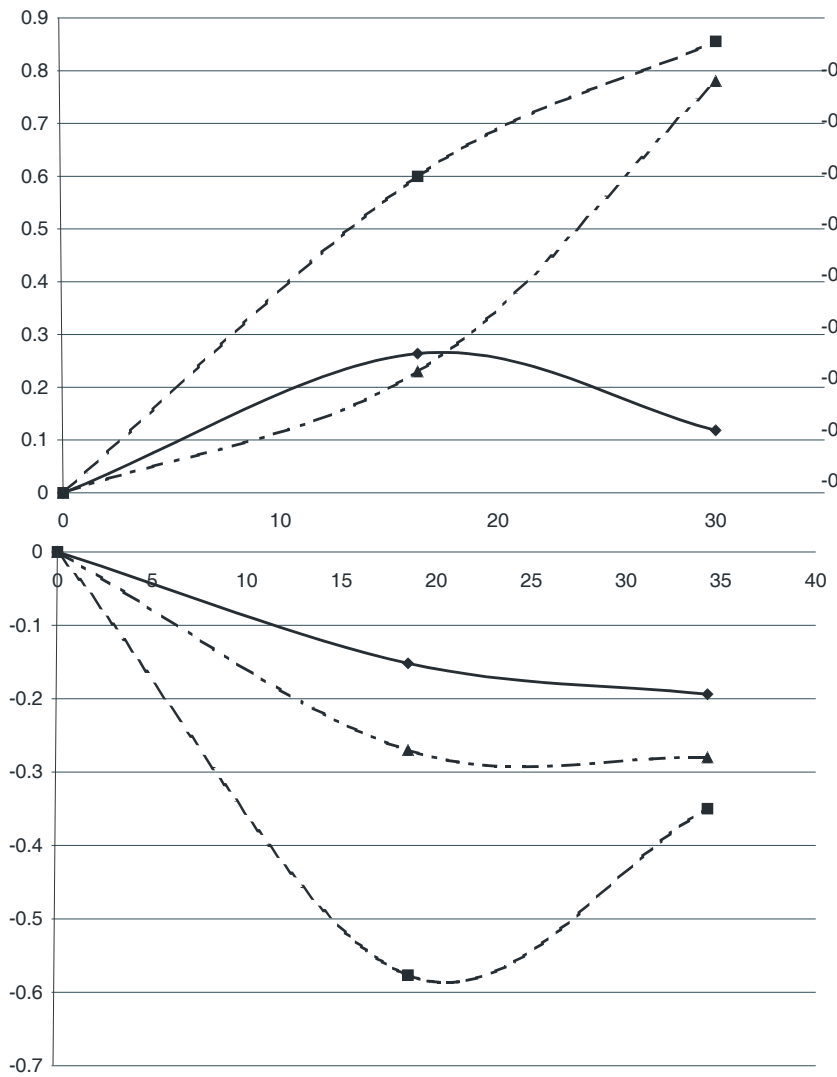

b)

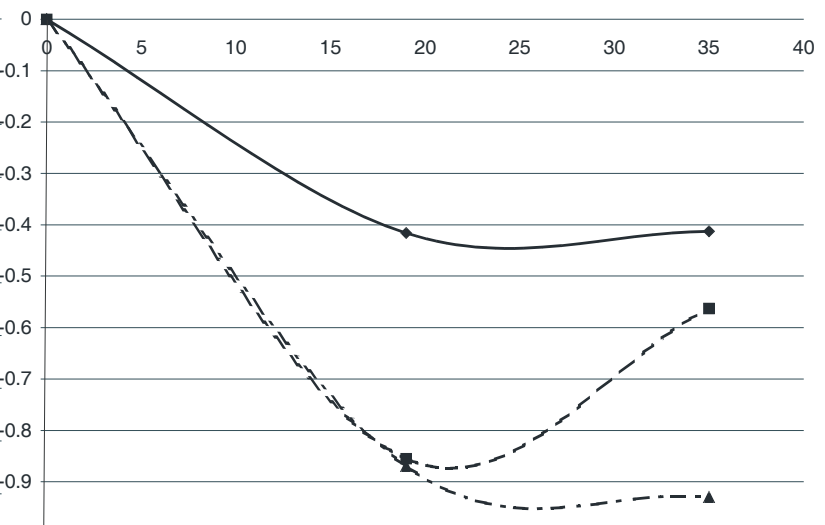

Fig 7. Vertical displacements of the radial ribs located: $\mathrm{a}$ - along the semi axis $\mathrm{a} ; \mathrm{b}$ - along the semi axis $\mathrm{b}$; $c$ - displacement in the central part of the quarter caused by loading structure own weight + temporary load all over the covering 


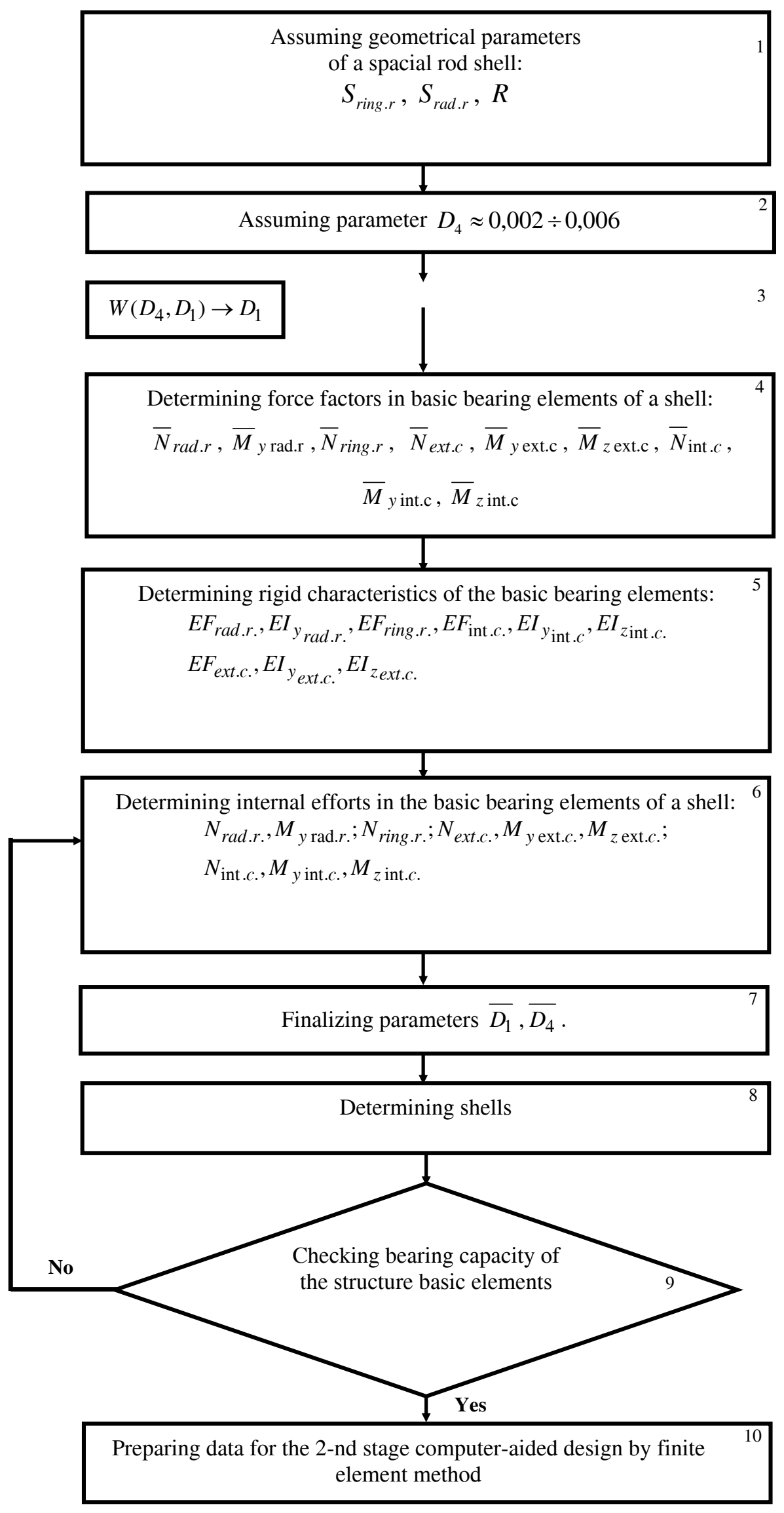

Fig 8. Principal block diagram of structure design 
8. Determining absolute values of internal efforts in the main bearing elements.

9. Finalising dimensionless spatial rigid parameters.

10. Determining geometrical characteristics of the main bearing elements from conditions of strength, stability.

11. Finding resulted thickness of a shell.

12. Algorithm recalculation, beginning with point 4, until conditions of strength in the main bearing elements while using geometrical characteristics obtained as a result of the previous iteration, are satisfied.

Finalising the parameters of structure intense deformed state with the help of numerical analysis by the finite element method. An approximate design procedure was checked while designing spatial rod covering over Central Stadium "Shakhtar" stands in Donetsk as one of the stages of complex reconstruction design [9]. In the course of the main bearing structures, the following basic defects have been exposed: continuing deformations of the stadium's whole framework, regular considerable wettings of the basic bearing structures by ground, storm and process waters. In order to rectify the above-mentioned defects stage-by stage reconstruction design of the stadium has been suggested. The 1-st stage - carrying out a set of procedures to stabilise structure deformations. The 2-nd stage - erecting an outer building with glazing by the stadium's perimeter. The 3-rd stage - making a protective covering above the stands.

To develop a covering design the following initial data were adopted: basic semi-axes: $a=123 \mathrm{~m}$, $b=85 \mathrm{~m}, a_{1}=93 \mathrm{~m}, b_{1}=50 \mathrm{~m}$. In accordance with recommendations in point 1,2 of the algorithm conventional curvature radius of internal index contour in curvature radius of internal index contour in plane $\mathrm{XOZ}$ is $R=1496,7 m$.

Space of the main bearing elements is $S_{\text {ring.r. }}=6,5 \mathrm{~m}, S_{\text {rad.r. }}=14,5 \mathrm{~m}$. Initial value of the dimensionless spatially rod parameter is $\bar{D}_{4}=0,005$, $\bar{D}_{1}=2,847 E-4$. The first snowy district with snow load intensity is $s=0,5 \mathrm{kN} / \mathrm{m}^{2}$. Dimensionless parameter of vertical displacements $w$ is connecting a link between dimensionless spatially-rigid parameters $\bar{D}_{1}$ and $\bar{D}_{4}$, and also one of major parameter of stress - strained state of spatially bar system (Fig 9 and Table 1).

Values of dimensionless parameters of internal efforts in the main bearing elements are determined with the help of graphs or approximate dependences given in Fig 10 and Table 2.

Testing the obtained data for goodness of fit was made with the help of program complex "SCAD 7.27". The task was solved in geometrically non-linear formulation. The results in Table 3.

Principal structural solution of a developed design of the covering and its general view is given in Figs 11, 12.

At present similar works are being carried out to develop a reconstruction design for "Olimpiiskij" Stadium (the former "Locomotiv" Stadium) in Donetsk.

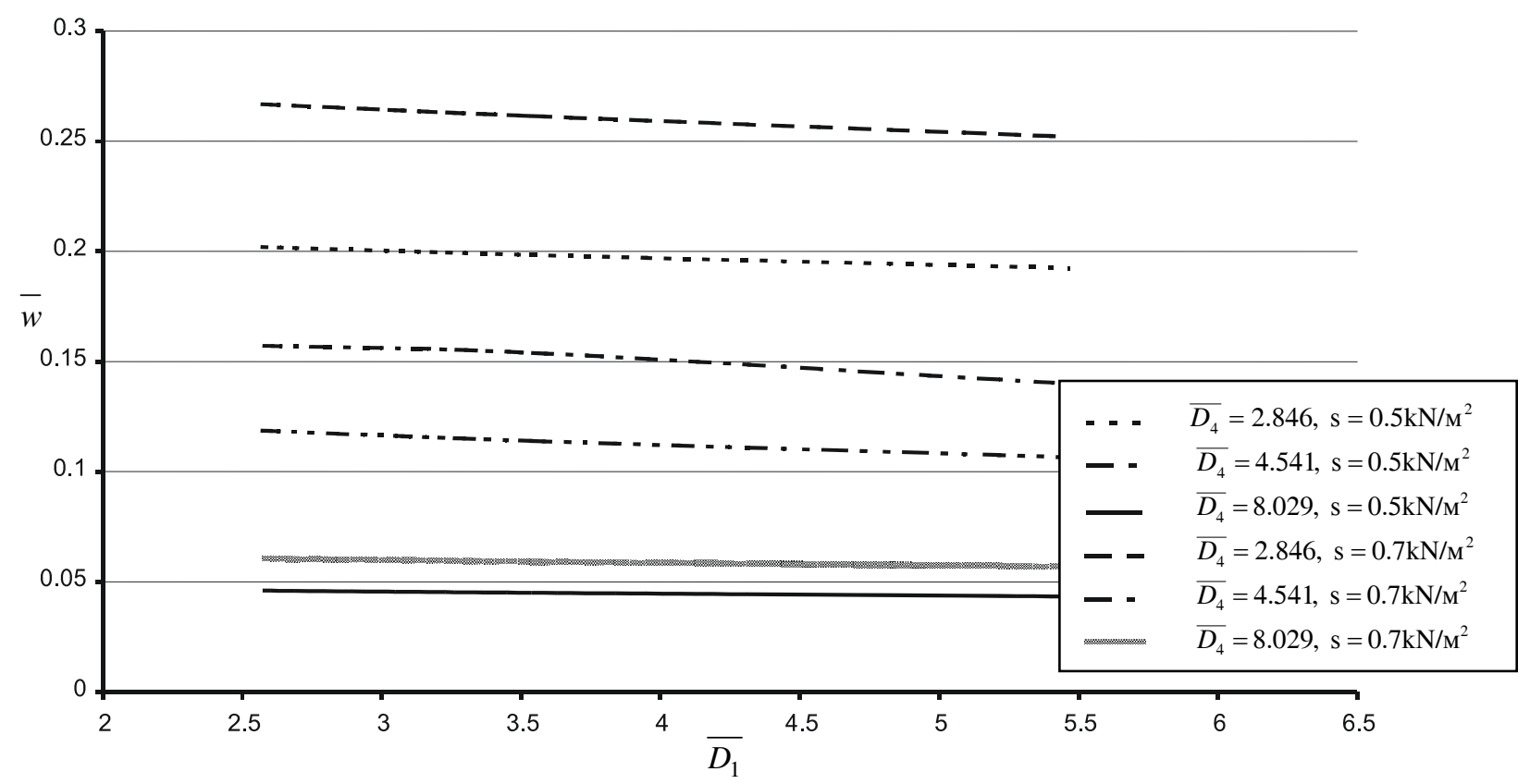

Fig 9. Dependences between dimensionless parameters of vertical displacements $\bar{w}$ and $\bar{D}_{1}, \bar{D}_{4}$ 
Table 1. Functional dependences of dimensionless argument of vertical displacements $w$ on dimensionless spatially-rigid parametres $\bar{D}_{1}, \bar{D}_{4}$

\begin{tabular}{|c|l|l|}
\hline $\bar{D}_{4}$ & \multicolumn{1}{|c|}{$s=0,5 \mathrm{kN} / \mathrm{m}^{2}$} & \multicolumn{1}{|c|}{$s=0,7 \mathrm{kN} / \mathrm{m}^{2}$} \\
\hline $1,017 \mathrm{E}-07$ & $\bar{w}\left(\bar{D}_{1}\right)=0,0105 \bar{D}_{1}^{2}-0,5122 \bar{D}_{1}+53,542$ & $\bar{w}\left(\bar{D}_{1}\right)=0,01105 \bar{D}_{1}^{2}-0,5981 \bar{D}_{1}+68,639$ \\
\hline 2,8456 & $\bar{w}\left(\bar{D}_{1}\right)=0,0002 \bar{D}_{1}^{2}-0,0051 \bar{D}_{1}+0,2135$ & $\bar{w}\left(\bar{D}_{1}\right)=0,00024 \bar{D}_{1}^{2}-0,007 \bar{D}_{1}+0,2833$ \\
\hline 4,5413 & $\bar{w}\left(\bar{D}_{1}\right)=0,0004 \bar{D}_{1}^{2}-0,0071 \bar{D}_{1}+0,1343$ & $\bar{w}\left(\bar{D}_{1}\right)=-0,0013 \bar{D}_{1}^{2}-0,0048 \bar{D}_{1}+0,1521$ \\
\hline 8,0285 & $\bar{w}\left(\bar{D}_{1}\right)=6 E-05 \bar{D}_{1}^{2}-0,0014 \bar{D}_{1}+0,0492$ & $\bar{w}\left(\bar{D}_{1}\right)=9,31 E-05 \bar{D}_{1}^{2}-0,002 \bar{D}_{1}+0,0634$ \\
\hline
\end{tabular}

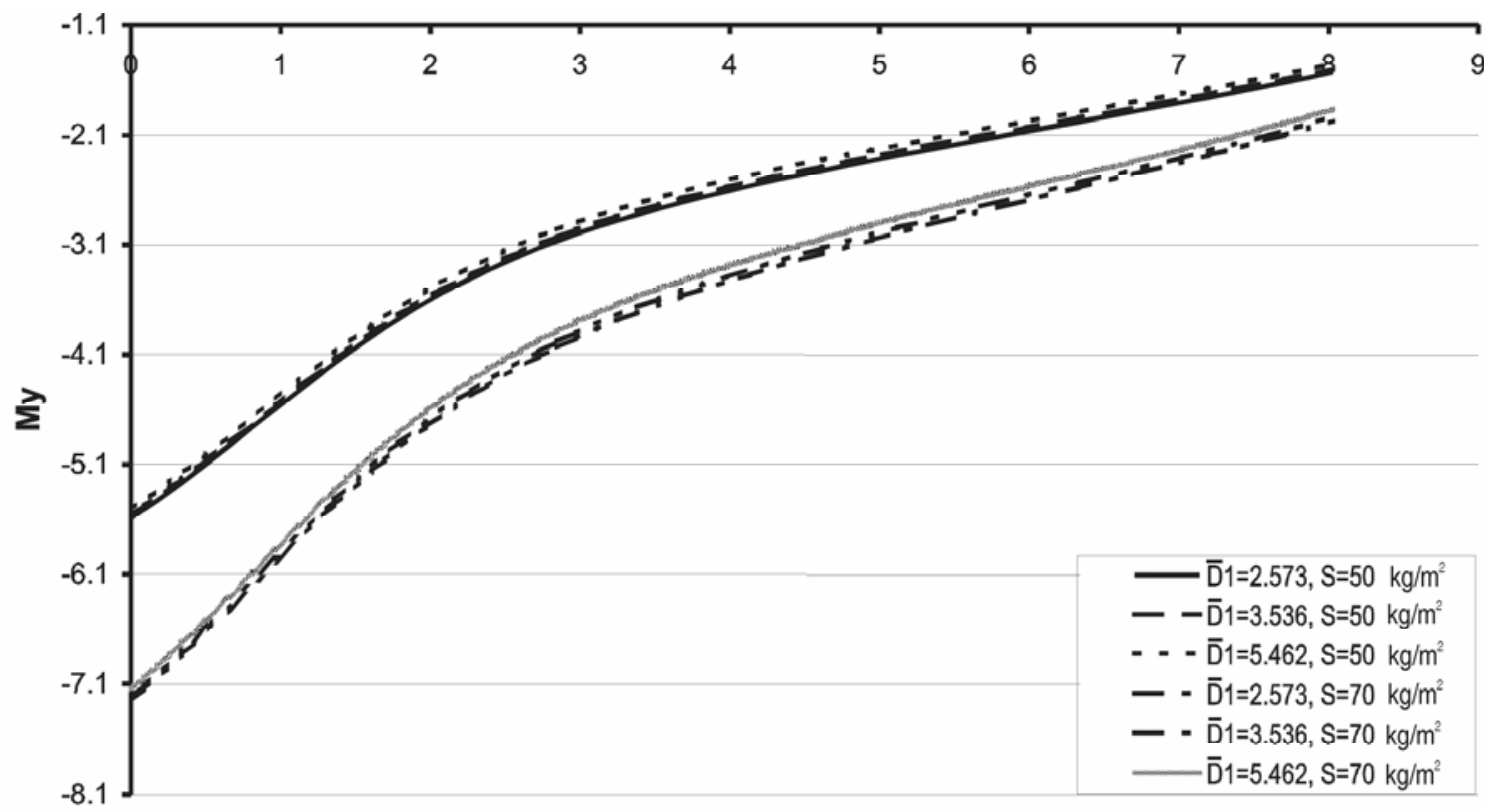

D4

Fig 10. Dependence of radial element being moment dimensionless parameter on $\bar{D}_{1}, \bar{D}_{4}$

Table 2. Functional dependencies of bending moment dimensionless parameter $\bar{M}$ in radial element on dimensionless spatially-rigid parameters $\bar{D}_{1}, \bar{D}_{4}$

\begin{tabular}{c|l|l}
\hline $\bar{D}_{1}$ & \multicolumn{1}{|c}{$s=0,5 \mathrm{kN} / \mathrm{m}^{2}$} & \multicolumn{1}{|c}{$\mathrm{s}=0,7 \mathrm{kN} / \mathrm{m}^{2}$} \\
\hline 2,573 & $\bar{M}\left(\bar{D}_{4}\right)=-0,073 \bar{D}_{4}^{2}+1,0906 \bar{D}_{4}-5,5813$ & $\bar{M}\left(\bar{D}_{4}\right)=-0,0908 \bar{D}_{4}^{2}+1,3857 \bar{D}_{4}-7,2455$ \\
\hline 3,536 & $\bar{M}\left(\bar{D}_{4}\right)=-0,0737 \overline{\mathrm{D}}_{4}^{2}+1,0958 \overline{\mathrm{D}}_{4}-5,5525$ & $\bar{M}\left(\bar{D}_{4}\right)=-0,0919 \overline{\mathrm{D}}_{4}^{2}+1,3952 \overline{\mathrm{D}}_{4}-7,2116$ \\
\hline 5,462 & $\overline{\mathrm{M}}\left(\overline{\mathrm{D}}_{4}\right)=-0,0748 \overline{\mathrm{D}}_{4}^{2}+1,1035 \overline{\mathrm{D}}_{4}-5,4986$ & $\overline{\mathrm{M}}\left(\overline{\mathrm{D}}_{4}\right)=-0,0938 \overline{\mathrm{D}}_{4}^{2}+1,4102 \overline{\mathrm{D}}_{4}-7,1476$ \\
\hline
\end{tabular}

\section{Conclusions}

1. The obtained system of dimensionless spatiallyrigid parameters allows to install the intercoupling between them and structure dimensionless SSS parameters, excluding the factor of scale.

2. The dependences obtained during experimental studies well coincide with datas of analytical investigations that allows using of it as a basis for elaboration of the engineering procedure of calculation and designing.
3. The obtained guidelines and the engineering procedure of calculation and designing allow with fidelity, indispensable for practice, to determine the geometrical parameters of structure, rigid characteristics of its principal elements and forces in them.

4. The validity of conclusions $1 \ldots .3$ is affirmed by data of experimental designing of structures of CS "Shakhtar" and RSC "Olympic" in Donetsk (Ukraine). 
Table 3. Comparative data of internal efforts in basic bearing elements

\begin{tabular}{|c|c|c|c|c|c|c|c|}
\hline \multicolumn{8}{|c|}{ Ring elements } \\
\hline \multirow{2}{*}{\multicolumn{2}{|c|}{ Type of internal effort }} & \multicolumn{3}{|c|}{ Engineering design } & \multicolumn{3}{|c|}{ SCAD 7.27} \\
\hline & & $b$ & $s$ & $a$ & $b$ & $s$ & $a$ \\
\hline \multicolumn{2}{|c|}{$\mathrm{N}, \mathrm{kN}$} & $-462,2$ & $-263,2$ & $-141,4$ & $-515,9$ & $-347,2$ & $-178,9$ \\
\hline \multicolumn{5}{|c|}{ Error, \% } & 10,41 & 24,2 & 20,94 \\
\hline \multicolumn{8}{|c|}{ Ring elements } \\
\hline \multirow{2}{*}{\multicolumn{2}{|c|}{ Type of internal effort }} & \multicolumn{3}{|c|}{ Engineering design } & \multicolumn{3}{|c|}{ SCAD 7.27} \\
\hline & & $b$ & $s$ & $a$ & $b$ & $s$ & $a$ \\
\hline \multicolumn{2}{|c|}{$\mathrm{N}, \mathrm{kN}$} & $-690,1$ & $-901,4$ & $-1834,4$ & $-662,5$ & & $-1755,5$ \\
\hline \multicolumn{5}{|c|}{ Error, \% } & 4,000 & & 4,492 \\
\hline My, & & $-638,2$ & $-465,0$ & $-1106,9$ & $-746,9$ & & $\overline{-1084,6}$ \\
\hline \multicolumn{5}{|c|}{ Error, \% } & 14,55 & & 2,054 \\
\hline \multicolumn{8}{|c|}{ Outer contour } \\
\hline \multicolumn{4}{|c|}{ Engineering design } & \multicolumn{4}{|c|}{ SCAD 7.27} \\
\hline $\mathrm{N}, \mathrm{kN}$ & \multicolumn{2}{|c|}{$\mathrm{M}_{\mathrm{z}}, \mathrm{kNm}$} & $\mathrm{M}_{\mathrm{y}}, \mathrm{kNm}$ & $\mathrm{N}, \mathrm{kN}$ & \multicolumn{2}{|c|}{$\mathrm{M}_{\mathrm{z}}, \mathrm{kNm}$} & $\mathrm{M}_{\mathrm{y}}, \mathrm{kNm}$ \\
\hline 6073,2 & \multicolumn{2}{|c|}{4851,3} & 1815,8 & 6074,0 & \multicolumn{2}{|c|}{5903,0} & 2274,9 \\
\hline \multicolumn{4}{|c|}{ Error, \% } & 0,0124 & \multicolumn{2}{|c|}{17,82} & 20,15 \\
\hline \multicolumn{8}{|c|}{ Internal contour } \\
\hline \multicolumn{4}{|c|}{ Engineering design } & \multicolumn{4}{|c|}{ SCAD 7.27} \\
\hline $\mathrm{N}, \mathrm{kN}$ & \multicolumn{2}{|c|}{$\mathrm{M}_{\mathrm{z}}, \mathrm{kNm}$} & $\mathrm{M}_{\mathrm{y}}, \mathrm{kNm}$ & $\mathrm{N}, \mathrm{kN}$ & \multicolumn{2}{|c|}{$\mathrm{M}_{\mathrm{z}}, \mathrm{kNm}$} & $\mathrm{M}_{\mathrm{y}}, \mathrm{kNm}$ \\
\hline$-5048,3$ & & & 1912,2 & $-4672,8$ & & & 2106,3 \\
\hline & & & & 8,034 & & & 9,215 \\
\hline
\end{tabular}
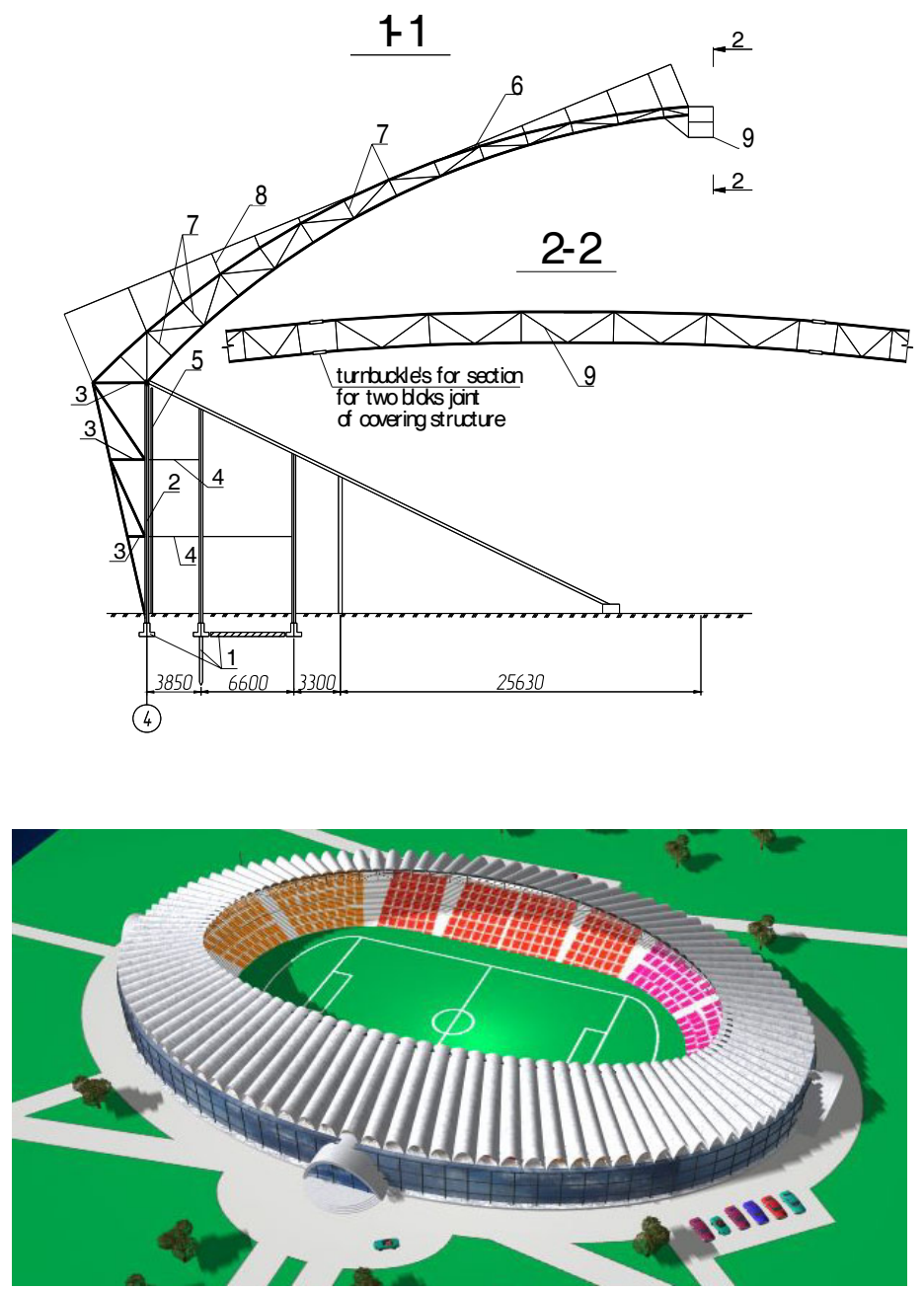

Fig 11. Cross-section of covering bearing frame: 1 - structures of foundation reinforcement,

2 - attached posts of flow section,

3 - longitudinal binding cross-bars,

4 - joining elements,

5 - glazing,

6 - bearing elements of covering structure frame and cantilever elements,

7 - horizontal connections on covering,

8 - covering fence structures,

9 - gallery for installing lighting and acoustical equipment

Fig 12. Top view of covering over stadium "Shakhtar" stands (a design) 


\section{References}

1. Revay, M.; Gavel, V. Thaumasite sulphate attack at the concrete structures of the Ference Puskas stadium in $\mathrm{Bu}$ dapest. Cement and Concrete Composites, 25(8), 2003, p. 1151-1155.

2. Mushchanov, V. F. Probabilistic-optimum design of sheet structures. In: Proc of European workshop Thin-walled steel structures, Wroclaw, Poland, 25-27 Sept 1996, p. 121-125.

3. Marighetti, J.; Wittwer, A.; De Bortoli, M.; Natalini, B; Paluch, M. and Natalini, M. Fluctuating and mean pressure measurements on a stadium covering in wind tunnel. Journal of Wind Engineering and Industrial Aerodynamics, 84(3), 2000, p. 321-328.

4. Killen, G. P. and Letchford, C. W. A parametric study of wind loads on grandstand roofs. Engineering Structures, 23(6), 2001, p. 725-735.

5. Barnard, R. H. Predicting dynamic wind loading on cantilevered canopy roof structures. Journal of Wind Engineering and Industrial Aerodynamics, 85(1), 2000, p. 47-57.

6. Ren, A.; Wen, Y; Chen, Ch. and Shi, J. Modeling of irregular structures for the construction simulation in virtual reality environments based on web. Automation in Construction, 13(5), 2004, p. 639-649.

7. Shea, K; Aish, R. and Gourtovaia, M. Towards integrated performance-driven generative design tools. Automation in Construction, 14(2), 2004, p. 253-264.

8. Àlyoshin, E. etc. Covering of large sporting arena in "Luzhniky" - designing, scientific investigations, building. Moscow: Forte, 1998. 144 p. (in Russian).

9. Horokhov, E. V.; Mushchanov, V. F. and Kasimov, V. R. Structures of fixed coverings above tribunes of stadiums. Makeyevka: Nord Computer, 2002. 156 p. (in Russian).
10. William, M. Redevelopment of Murrayfield Stadium, Edinburgh, UK. Structural Engineering International, 3/99, 1999, p. 195-197.

11. Chapman, D. K. Madejski Stadium, Reading, UK. Structural Engineering International, 3/99, 1999, p. 191-193.

12. Dykhovichny, Yu. A. Wide-span constructions of Olympiad-80 buildings in Moscow. Moscow: Stroyizdat, 1982. 277 p. (in Russian).

13. Kornishin, M. S. Non-linear problems of a plate theory both depressed shells and methods of their solution. Moscow, 1964 (in Russian).

14. Horokhov, E. V.; Mushchanov V. F. and Kasimov V. R. The effect external index contour dimensionless spatialrigid parameters on the large-cut shell stress and strain state dimensionless parameter. In: Steel structures, Vol V, Part 1. Makeyevka: DNACEA, 2002, p. 85-88 (in Russian).

15. Samul, V. I. The principles of a theory of elastic strength and plasticity. Moscow: Higher school, 1982. 263 p. (in Russian).

16. Nazarov, A. A. The principles of a theory and methods of calculation of depressed shells. Leningrad, 1966. 302 p. (in Russian).

17. Kasimov, V. R. Experimental investigations of model of a net-shaped shell with cut on the elliptical plan. Transactions of DonSACEA (Вісник ДонДАБА), Vol 2003-2 (39), Part I. Makeyevka: DNACEA, 2003, p. 58-64 (in Russian).

18. Mushchanov, V. F.; Kasimov, V. R. The approximated calculation and designing technique of spatial rod shells with large cut. Transactions of PSACEA (Вісник ПДАБА), Vol 70-71. Dnepropetrovsk: PSACEA, 2003, p. 72-76 (in Russian).

\section{NAUJI SIŪLYMAI, KAIP ANALIZUOTI IR PROJEKTUOTI NUOLATINĘ DANGĄ VIRŠ STADIONO TRIBŪNŲ}

\section{E. Horokhov, V. Mushchanov, V. Kasimov}

Santrauka

Apžvelgiama nuolatinè danga yra teigiamojo kreivumo nupjautinis strypinis kevalas, padètas ant elipsinio plano. Nedimensinių erdviškai standžių rodiklių sistema yra gauta šiai konstrukcijai ir lemia konstrukcijos įtemptojo ir deformuotojo būvio, veikiant pasirinktosioms apkrovoms, ypatybes. Pateikiami skaitmeninių ir eksperimentinių tyrimų ir eksperimentinio projektavimo rezultatai, pasiūlytos naujos projektavimo ir skaičiavimo inžinerinès atlikimo metodikos galimybès.

Reikšminiai žodžiai: nedimensiniai erdviškai standūs rodikliai, erdvinè strypinè sistema, nuolatinis apvalkalas.

Yevheny HOROKHOV. Rector, Head of Dept of Steel Structures, Dept Donbass National Academy of Civil Engineering and Architecture, Makeyevka, Ukraine. Member of an Academy of Higher Scool of Ukraine, member of Russian Academy of Architecture and Building Sciences, President of the Ukrainian Association of Steel Structures, MICE (Fellow), DSc, Prof, Winner of the State Premium of Ukraine in the sphere of science and engineering. The real behaviour and service reliability of building metal structures - sphere of his scientific activity.

Vladimir MUSHCHANOV. Vice-Rector of scientific activity, chief of "Theoretical and applied mechanins" Dept of the Donbass National academy of Civil Engineering and Architecture, Makeyevka, Ukraine. DSc, Prof, member of the Academy of Building of Ukraine, MICE (member). The elaboration computational methods and designing of thin-walled spatial structures (membrane structures of large-span roofs and vertical cylindrical tanks, first of all) - sphere of his scientific activity.

Vadim KASIMOV. PhD, Assoc Professor of "Theoretical and applied mechanins". Dept of the Donbass National Academy of Civil Engineering and Architecture, Makeyevka, Ukraine. Sphere of scientific activity - the elaboration of computational methods and designing techniques of large-span spatial rod shell roofs. 